
менном этапе

Научная статья

УДК 342.417

DOI 10.18101/2658-4409-2021-4-35-41

\title{
О КОНСТИТУЦИОННОМ РЕГУЛИРОВАНИИ РОССИЙСКОЙ ЭКОНОМИКИ НА СОВРЕМЕННОМ ЭТАПЕ
}

\author{
(С) Дагангаров Сергей Владимирович \\ старший преподаватель, \\ Бурятский государственный университет имени Доржи Банзарова \\ Россия, 670000, г. Улан-Удэ, ул. Сухэ-Батора, 6 \\ serdag13@yandex.ru
}

Аннотация. В статье рассматриваются сложившиеся в науке конституционного права
подходы к оценке экономического содержания Конституции Российской Федерации.
Автор анализирует перспективы междисциплинарного изучения экономических про-
цессов, происходящих в Российской Федерации, с использованием категории «эконо-
мическая конституция». Несмотря на имеющиеся в науке конституционного права
дискуссии по поводу содержания «экономической конституции», делается вывод о
необходимости дальнейших конституционно-правовых и экономических исследова-
ний в данной области. Конституция государства при этом рассматривается не как
формализованный юридический документ, но как развивающееся «живое право»,
неразрывно связанное с богатой практикой Конституционного Суда Российской Фе-
дерации в области защиты экономических, а порой и социальных прав и свобод граж-
дан. В статье оценивается влияние конституционных поправок 2020 г. на перспективы
дальнейшего совершенствования социальной и экономической политики российского
государства.

Ключевые слова: Конституция России, экономическая конституция, конституционная экономика, экономическая политика, конституционные поправки, экономические и социальные права граждан.

\section{Для цитирования}

Дагангаров C. В. О конституционном регулировании российской экономики на современном этапе // Вестник Бурятского государственного университета. Юриспруденция. 2021. Вып. 4. С. 35-41.

Переживаемые российской экономической системой кризисные явления, связанные с обстоятельствами как внутреннего (многолетняя зависимость от сырьевого сектора и мировых цен на нефть, отставание в области высокотехнологичных производств), так и внешнего порядка (санкционная политика западных стран, низкий инвестиционный уровень) обусловливает поиск новых подходов к решению старых проблем. Методологических возможностей экономической науки в условиях, когда процессы товарообмена и инвестиционной деятельности находятся в прямой зависимости от проводимого государством политического курса и его юридического оформления, становится недостаточно. В свою очередь юриспруденция не способна выработать оптимальные варианты правового регулирования деятельности субъектов хозяйствования без понимания того, как и почему протекают те или иные экономические процессы. Все это требует междисциплинарного подхода к решению накопившихся комплексных проблем. Следует согласиться с Д. А. Керимовым, отмечавшим, что «наибольших успехов 
добьются те исследователи, которые... настойчиво и последовательно расширяют диапазон исследовательских усилий путем широкомасштабного и интенсивного привлечения инструментов и методов анализа, знаний и результатов, накопленных и используемых в других научных областях» [5, с. 19].

В области взаимодействия юридической и экономической науки одним из подобных междисциплинарных направлений стала конституционная экономика. Основные теоретические положения этого направления научной мысли были сформулированы выдающимся американским экономистом Дж. Бьюкененом, удостоенным Нобелевской премии по экономике за изучение конституционных основ принятия экономических и политических решений. Субъекты принятия экономических и политических решений стремятся осуществить свой выбор наиболее оптимальной альтернативы, обеспечивающей качественное развитие экономической системы. Сделать это без надлежащей конституционной основы практически невозможно, поэтому элементы конституционализма и экономики в данном случае неразрывны [9, с. 159]. Конституция призвана, по мнению Дж. Бьюкенена, обеспечить оптимальное развитие общественной системы через максимально возможное удовлетворение потребностей ее членов, обеспечить их социальные и экономические интересы.

Нормы Конституции Российской Федерации, закрепляющие основополагающие социальные и экономические принципы, во многом определяют характер отечественной экономической системы. Причем речь здесь следует вести не только о положениях главы 1, но и о множестве иных статей, «разбросанных» по всему тексту Основного закона. В отечественной науке конституционного права эти нормы в своем единстве получили название «экономическая конституция». Следует отметить, что не все исследователи позитивно относятся к появлению подобной терминологии. По мнению профессора В. Е. Чиркина, введение в научный оборот понятия «экономическая конституция» приводит к неопределенности, «коллизиям между сложившимися в науке конституционного права понятиями, затрудняет правовой анализ. С точки зрения юриспруденции не может существовать никакой особой экономической конституции. Принципы экономической жизни формулирует сам Основной закон (в его традиционном формально-юридическом понимании)» [10, с. 3]. С другой стороны, профессор Г. А. Гаджиева полагает, что положения, определяющие развитие экономических отношений в стране, будучи закрепленными в Конституции, создают общий базис для иных конституционных норм, которые в своем единстве могут быть условно обозначены как «экономическая конституция» [2, с. 21]. Представляется все же, что использование понятия «экономическая конституция» для обозначения положений Основного закона, затрагивающих экономические вопросы, не посягает на авторитет Конституции в целом и не размывает четкость юридической терминологии.

Сегодня необходимость выстраивания оптимальной конституционноправовой модели протекающих экономических процессов признается и на межгосударственном уровне. Так, в декларации совещания Генеральной Ассамблеи ООН о верховенстве права от 19.09.2012 г. провозглашается, что «верховенство права как базовый принцип развития юридической системы любого демократического государства играет важнейшую роль для осуществления устойчивого экономического роста и развития». Также в ней отмечается «принципиальное 
C. В. Дагангаров. О конституционном регулировании российской экономики на современном этапе

значение справедливой и стабильной правовой системы для обеспечения устойчивого и равноправного развития, экономического роста и занятости, мобилизации инвестиций и содействия развитию предпринимательства» $[9$, с. 160].

По мнению профессора Г. А. Гаджиева [6, с. 105], в нашей стране экономическая конституция охватывает:

1) конституционные положения о свободе экономической деятельности, едином экономическом пространстве, многообразии и равноправии различных форм собственности, защите конкуренции, о социальном характере государства;

2) конституционные нормы об основных экономических правах и свободах, а также о конституционных гарантиях предпринимательства; о значении общепризнанных норм и принципов международного права и норм, содержащихся в международных договорах РФ;

3) нормы, устанавливающие конституционный экономический публичный порядок (об ограничении экономических прав и свобод граждан; о полномочиях органов государственной власти различного уровня в области экономической политики и предпринимательства).

При этом перечисленные положения Конституции не действуют в отрыве от других ее норм, а образуют с ними системное единство. Так, важнейшее значение для реализации экономической политики Российского государства имеют положения Конституции, регулирующие функционирование федеративной системы. Как верно указывает В. И. Головченко, «конституционная модель экономического федерализма позволяет эффективно реализовать принцип «единства во множестве» [3, с. 17], разграничивая полномочия между федеральной и региональной государственной властью в этой области и позволяя субъектам РФ выстраивать свою бюджетную политику в общих рамках, определенных федеральным центром. Свою роль играют и нормы Конституции, определяющие взаимоотношение российского права с международным. Особое значение эти положения получили в связи с вступлением нашей страны в ВТО и усилением глобализационных процессов в экономике. Тем самым экономическая конституция по сути своей объединяет разные нормы Основного закона страны, касающиеся вопросов, на первый взгляд не связанных с системой хозяйствования.

Важную роль в адаптации конституционных норм и принципов к реалиям конкретных экономических процессов играет практика Конституционного Суда Российской Федерации. В его решениях прослеживается, с одной стороны, курс на обеспечение закрепленных в Основном законе социальных и экономических прав граждан, с другой - попытка выявить смысл абстрактных конституционных принципов и выработать на их основе четкие ориентиры для развития федерального и регионального законодательства.

Как указывает профессор Н. С. Бондарь, за время своей работы Конституционный суд РФ более одной трети своих решений вынес по вопросам, связанным с защитой экономических прав граждан. Особенно часто в фокусе его внимания оказывались налоговые правоотношения: «Значение Конституционного суда РФ как инструмента конституционализации налогового права в большой степени определяется тем, что он является важным институтом гарантирования конституционных прав налогоплательщиков, средством разрешения налоговых споров, возникающих на уровне не только правоприменительной, но и налоговозаконотворческой деятельности» [1, с. 226]. Важным направлением деятельности 
высшего органа конституционного контроля России являлась и защита права собственности, которое не просто является основой экономической деятельности, но и непременным условием личной свободы человека. В ряде случае Конституционный суд вставал и на защиту публичных экономических интересов российского государства и его граждан. Так, в деле бывших акционеров компании «ЮКОС», обосновывая отказ от выплаты присужденной им Европейским судом по правам человека компенсации, Конституционный суд отметил, что «сама по себе выплата... компании, выстроившей незаконные схемы уклонения от налогообложения столь значительной денежной компенсации из бюджетной системы, которая регулярно не получала от нее в должном объеме огромные суммы налоговых платежей, необходимых в том числе для выполнения публичных обязательств перед всеми гражданами, преодоления финансового и экономического кризиса (выделено нами. - C. Д.), противоречит конституционным принципам равенства и справедливости в налоговых правоотношениях» $[12$, c. 18$]$.

Тем самым «экономической конституцией» современного Российского государства следует считать не только тест собственно Основного закона страны, устанавливающий принципы экономической системы, но и сформировавшуюся практику Конституционного суда Российской Федерации по вопросу защиты экономических (в порой и социальных) прав граждан, а также публичных экономических интересов.

Следует отметить, что Конституция России как правовая основа экономического развития страны не лишена и определенных недостатков. В качестве одного из таковых можно указать отсутствие отдельной главы, определяющей принципиальные положения государственной политики в области экономического развития, а также отсутствие четкой связи между «экономическими» нормами и принципом социального государства. Первый недостаток носит в большей степени юридико-технический характер. Конституции многих стран (Италия, ФРГ, Португалия, Греция, Швейцария, Бразилия и др.) содержат отдельную главу экономического характера, в которой в системной единстве содержатся нормы о принципах рынка, поддержке бизнеса, функциях собственности, финансовой системе. В этой связи можно заметить, что в Конституции СССР 1977 г. вторая глава называлась «Экономическая система». В настоящей Конституции РФ от такого подхода отказались, и статьи, так или иначе затрагивающие экономические вопросы, оказались распределены по всему ее тексту. Представляется, что это «шаг назад» в юридико-техническом построении Основного закона страны, затрудняющий целостное восприятие такого важного элемента в конституционно-правовом регулировании.

Что касается второго указанного выше недостатка, то одной из основных тенденций современного конституционного развития является признание тесной взаимосвязи экономических и социальных процессов. Многочисленные экономические кризисы XX и XXI вв. показали неэффективность классической либеральной модели хозяйствования. Отказ от государственного вмешательства в экономику, политики «выравнивания» доходов населения, социальной ответственности рынка привел к серьезному социальному напряжению. Как пишет председатель Конституционного суда РФ В. Д. Зорькин: «В период кризиса стали очевидны издержки доктрин, трактующих право как “чистую” форму в отрыве от 
C. В. Дагангаров. О конституционном регулировании российской экономики на современном этапе

ее содержания и не учитывающих взаимосвязь юриспруденции и экономики как прикладных наук, что, по существу, ведет к игнорированию системного подхода как методологической основы профессионализма» [4, с. 472]. Конституция России 1993 г., являясь, по сути своей, либеральной конституцией, несет в себе и присущие такого рода документу достоинства и недостатки. С одной стороны, отказ от плановой экономики позволил закрепить в главе 1 Основного закона принципы свободного рынка (собственность, конкуренция, предпринимательство и т. д.), с другой — в текст не вошли нормы о социальной ответственности бизнеса и собственности, характерные для конституций ряда зарубежных стран, провозгласивших социальную государственность (например, ФРГ). Частично решить эту проблему были призваны конституционные поправки, внесенные законом от 14.03.2020. Так, текст Основного закона был дополнен статьей 75.1, согласно которой «в Российской Федерации создаются условия для устойчивого экономического роста и повышения благосостояния граждан, для взаимного доверия государства и общества, гарантируются защита достоинства граждан и уважение человека труда, обеспечиваются сбалансированность прав и обязанностей гражданина, социальное партнерство, экономическая, политическая и социальная солидарность» ${ }^{1}$. Из содержания данной статьи можно сделать вывод, что для авторов конституционных поправок экономическое развитие непредставимо без выверенной социальной политики, а экономика страны может носить только социально ориентированный характер. Проявляющийся в таком подходе отказ от идей классического либерализма с его государством - «ночным сторожем», не влияющим на экономические процессы и, по существу, уклоняющимся от решения задач по обеспечению достойной жизни большинства своих граждан, позволяет говорить о возможности полноценного обновления законодательной системы в области экономической политики и социального обеспечения, наполнения реальным содержанием статей Основного закона о России как социальном государстве.

В заключение следует еще раз отметить, что междисциплинарный подход к анализу происходящих в нашей стране экономических процессов, основанных на концепции «экономической конституции», как представляется, должен способствовать более полному и объективному изучению столь сложной, но при этом важной для развития российского государства темы. Учет не только текста Основного закона, но и сформулированных Конституционным судом Российской Федерации правовых позиций по ключевым социальным и экономическим вопросам позволит выработать более четкое представление о направлениях дальнейшего реформирования экономической системы нашей страны и ее юридическое оформление. Можно согласиться с мнением профессора В. Е. Чиркина о том, что многие конституционные положения не получили еще должной практической реализации (об этом нам говорят многочисленные социологические исследования уровня безработицы, бедности, да и просто опросы граждан) [11, c. 12]. В то же время принятые в 2020 г. конституционные поправки, усилившие социальную составляющую текста Основного закона, внушают надежду на будущее изменение как отраслевого законодательства, так и политики государства

1 Конституция Российской Федерации. URL: http://www.consultant.ru/document/ cons_doc_LAW_28399/(дата обращения: 03.12.2021). Текст: электронный. 
по наиболее проблемным направлениям социальной и экономической жизни нашей страны

\section{Литература}

1. Бондарь Н. С. Экономический конституционализм России: очерки теории и практики. Москва: Норма, 2017. 272 с. Текст: непосредственный.

2. Гаджиев Г. А. Конституционная экономика и рациональность в конституционном праве // Ежегодник конституционной экономики. 2018. / ответственные редакторы С. А. Авакьян, П. Д. Баренбойм, В. В. Комарова. Москва: Лум, 2018. С. 18-43. Текст: непосредственный.

3. Головченко В. И. Тенденции коэволюции конституционной модели и экономической системы России на современном этапе // Вестник Поволжского института управления. 2020. № 3. С. 16-23. Текст: непосредственный.

4. Зорькин В. Д. Конституционно-правовое развитие России. Москва: Норма: ИНФРА-М, 2011.720 с. Текст: непосредственный.

5. Керимов Д. А. Методология права: предмет, функции, проблемы философии права. Москва: Ин-т социал.-полит. исслед. РАН, 2009. 520 с. Текст: непосредственный.

6. Комментарий к Конституции Российской Федерации / под редакцией В. Д. Зорькина, Л. В. Лазарева. Москва: Эксмо, 2009. 1056 с. Текст: непосредственный.

7. Нарутто С. В. Роль Конституционного Суда РФ в защите экономического порядка и прав собственности // Ежегодник конституционной экономики. 2018 / ответственные редакторы С. А. Авакьян, П. Д. Баренбойм, В. В. Комарова. Москва: Лум, 2018. С. 288307. Текст: непосредственный.

8. Очерки конституционной экономики. 23 октября 2009 года / ответственный редактор Г. А. Гаджиев. Москва: Юстицинформ, 2009. 280 с. Текст: непосредственный.

9. Сергеев А. М. Становление и развитие экономической теории конституции // Труды VII Всероссийского симпозиума по экономической теории. Екатеринбург: Институт экономики Уральского отделения РАН, 2016. С. 159-160. Текст: непосредственный.

10. Чиркин В. Е. «Экономическая конституция» и управление «на местах» (российский и зарубежный опыт) // Гражданин и право. 2015. № 3. С. 3-15. Текст: непосредственный.

11. Чиркин В. Е. Социально-экономический вектор конституционного развития: сравнительное измерение // Журнал зарубежного законодательства и сравнительного правоведения. 2018. № 1. С. 8-15. Текст: непосредственный.

12. Шишкин С. Н. Правовой анализ экономики: постановка проблемы, конституционные критерии // Бизнес, менеджмент и право. 2020. № 1(45). С. 16-20. Текст: непосредственный.

Статья поступила в редакцию 23.11.2021; одобрена после рецензирования 26.11.2021; принята к публикации 14.12.2021. 


\title{
ON CONSTITUTIONAL REGULATION OF THE RUSSIAN ECONOMY AT THE PRESENT STAGE
}

\author{
Sergey V. Dagangarov \\ Senior Lecturer of Constitutional, Administrative \\ and Municipal Law Department, \\ Dorzhi Banzarov Buryat State University \\ 6 Sukhe-Batora St., Ulan-Ude 670000, Russia \\ serdag13@yandex.ru
}

Abstract. The article considers the approaches of constitutional law to assessment of the economic content of the Constitution of the Russian Federation. We have analyzed the prospects for an interdisciplinary study of the economic processes in the Russian Federation, using the category of "economic constitution". Despite the discussions on the content of the "economic constitution" in the constitutional law science, we have concluded that there is a need for further constitutional, legal and economic research in this area. At the same time, the Constitution is regarded not as a formalized legal document, but as a developing "living law" inextricably entwined with the rich practice of the Constitutional Court of the Russian Federation in the field of protecting economic and, occasionally, social rights and freedoms of citizens. The article assesses the impact of the 2020 constitutional amendments on the further development of social and economic policy in the Russian state.

Keywords: the Constitution of the Russian Federation, economic constitution, constitutional economics, economic policy, constitutional amendments, economic and social rights of citizens.

\section{For citation}

Dagangarov S. V. On Constitutional Regulation of the Russian Economy at the Present Stage. Bulletin of Buryat State University. Law. 2021; 4: 35-41 (In Russ.).

The article was submitted 23.11.2021; approved after reviewing 26.11.2021; accepted for publication 14.12.2021. 